\title{
HELP THAT HuRTS: How DOL's HOME CARE RULE HARMS PEOPLE WITH DisABILITIES AND CAREGIVERS
}

\author{
Emily Munson, JD, MA*
}

I. HOME CARE WORKERS AND THE FLSA ...........................435

II. ChALlENGES to the COMPANIONSHIP EXEMPTION ........436

A. Legislative Challenges........................................ 437

B. Challenges through Litigation ............................. 439

C. Administrative Challenges................................... 444

D. Home Care Association Challenge ........................ 448

III. EFFECTS FOR RECIPIENTS OF CARE ...............................451

A. Delivery of Services............................................. 451

B. State Implementation ........................................... 453

C. Harms to Recipients of Care.................................. 455

IV. CONSEQUENCES FOR HOME CARE WORKERS .................460

A. Home Care Worker Representation ....................... 461

B. Pragmatic Effects for Home Care Workers............. 466

V. ConCLUSION..............................................................470

People with disabilities and their caregivers work together every day. In addition to the obvious - caregivers assisting clients with disabilities in performing activities of daily living-the two groups have frequently come together in support of a cohesive policy agenda. ${ }^{1}$ In 2011, when the Department of Labor (DOL) issued a notice of proposed

*LL.M. Candidate, 2016, Indiana University Robert H. McKinney School of Law. I would like to thank Melissa L. Keyes, J.D., M.S., for her diligent editing. Of course, any errors that remain are my own.

1 ADAPT Disability Rights Activists and SEIU Home Care Attendants Tell Congress: Community Choice is a Right, PR NEWswIRE (Apr. 29, 2009), http://www.prnewswire.com/news-releases/adaptdisability-rights-activists-and-seiu-home-care-attendants-tell-congresscommunity-choice-is-a-right-62029822.html [http://perma.cc/G5QPXQLU]; Edgar Walters, Conservatives Join Push to Pay Care Workers More, TEX. TRIB. (Mar. 3, 2015), http://www.texastribune.org/2015/ 03/03/among-conservatives-push-pay-attendants-more/ [http://perma.cc/ VGQ7-AWFM]. 
rulemaking to limit the companionship exemption to the Fair Labor Standards Act (FLSA), the two groups' interests diverged.

Advocacy groups for home care workers, as well as lobbying groups for the minorities that comprise a significant portion of the home care worker pool, had been clamoring for minimum wage and overtime protections for years. To these groups, the denial of FLSA protections to workers constituted an injustice. ${ }^{2}$ However, disability rights groups were concerned that the recipients of care-also historically marginalized-lacked the resources, both individually and governmentally, to cover the benefits home care workers desired, as Congress itself recognized when debating the companionship exemption. ${ }^{3}$ The disability community argued that the DOL's failure to first ensure adequate infrastructure to support FLSA protections for workers jeopardized those receiving care. ${ }^{4}$

Part I of this paper begins by exploring how the federal government has classified domestic workers since the inception of the FLSA. Part II explores the genesis of the companionship exemption, as well as the challenges it has faced from the legislative, judicial, and administrative branches of government. Finally, the most recent challenge to the DOL's interpretation of the home care rule, Home Care Ass'n of America v. Weil, ${ }^{5}$ is discussed.

Subsequent parts of the paper focus on the harm that will result from implementation of the new home care rule. Part III describes why the well-being of people with disabilities is jeopardized by implementation of the rule, and details how states are grappling with the new regulatory requirements.

2 NELP Applauds Historic Decision to Uphold Minimum Wage and Overtime Rights for Home Care Workers, NELP (Aug. 21, 2015), http://www.nelp.org/news-releases/nelp-applauds-historic-decision-touphold-minimum-wage-overtime-rights-for-home-care-workers/ [http://perma.cc/8TV7-DVGT].

${ }_{3}^{3}$ See 119 Cong. REC. 24,797 (1973) (statement of Sen. Dominick); id. at 24,789 (statement of Sen. Johnston).

${ }^{4}$ DOL Proposes Changes to Companionship Exemption HURT People with Disabilities!, ADAPT, http://www.adapt.org/main/dol [http:// perma.cc/M2A3-3ZCH] (last visited Apr. 11, 2016).

${ }^{5}$ Home Care Ass'n. of Am. v. Weil, 78 F. Supp. 3d 123, 128 (D.D.C.), rev'd sub nom., 799 F.3d 1084 (D.C. Cir. 2015). 
Part IV explains why the rule will not actually benefit home care workers, and even may leave some worse off than before.

\section{HOME CARE WORKERS AND THE FLSA}

In 1938, Congress enacted the FLSA. ${ }^{6}$ The FLSA was deemed necessary to address "labor conditions detrimental to the maintenance of the minimum standard of living necessary for health, efficiency, and general well-being of workers." 7 Its protections included minimum wage and overtime standards. ${ }^{8}$

However, not all employees benefited. ${ }^{9}$ FLSA excluded from its minimum wage and overtime protections certain classes of worker, including domestics and other workers traditionally performing services in the home. ${ }^{10}$ As such, those workers providing care for the elderly and disabled were not protected by the FLSA at its inception.

In 1961 and 1966, the FLSA was amended to provide coverage to certain additional employees through "enterprise coverage."11 For the first time, workers would receive minimum wage and overtime protections based on the size of their employer, as opposed to the specific nature of their individual work. Thus, if a domestic worker was employed by an agency (or other enterprise) with gross annual sales of $\$ 250,000$ or more, she was entitled to receive the minimum wage and additional compensation for overtime. ${ }^{12}$ However, these protections were short-lived.

Less than a decade later, in 1974, Congress explicitly exempted several categories of domestic employees from

\footnotetext{
${ }^{6}$ Codified as amended at 29 U.S.C. $§ 201$ et seq. (2016).

${ }^{7}$ Codified at 29 U.S.C. $\$ 202$ (a) (2016).

829 U.S.C. $\S \S 206-207$ (2016).

${ }^{9}$ In fact, only about one-fifth of the American labor force was covered by FLSA. Jonathan Grossman, Fair Labor Standards Act of 1938: Maximum Struggle for a Minimum Wage, U.S. DEP'T LAB., http://www.dol.gov/oasam/programs/history/flsa1938.htm [http:// perma.cc/A5D3-QCMJ] (last visited Apr. 11, 2016).

10 See 29 U.S.C. $\S \S 201-219$ (2016).

11 See 29 U.S.C. $§ 203(\mathrm{r})-(\mathrm{s})(2016)$.

12 See Fair Labor Standards Amendments of 1966, Pub. L. No. 89601, 80 Stat. 830,836 (1966) (current version at 29 U.S.C. $§ 203(\mathrm{~s})(1)$ (2016) (current limit is $\$ 500,000)$ ).
} 
FLSA coverage by implementing the "companionship exemption." Exempted companions included "any employee employed on a casual basis . . . to provide babysitting services,"13 as well as those "employed . . . to provide companionship services for individuals who (because of age or infirmity) are unable to care for themselves." 14 The Secretary of Labor was left to define the specifics. ${ }^{15}$

In 1975, the DOL reported receiving a variety of comments in response to its proposed implementing regulations, from groups as diverse as law firms to working mothers. ${ }^{16}$ Based on these comments, the DOL amended the final rule to: clarify that individuals engaged in a home business are not domestic service employees, simplify recordkeeping mandates for live-in caregivers, and describe timekeeping methods. ${ }^{17}$ Perhaps most controversial, Wage and Hour Division Administrator Betty Murphy determined that third parties could avail themselves of the companionship exemption since the exemption applies to "any employee."18 This meant that domestic service workers affiliated with agencies constituting enterprises under the FLSA would no longer be entitled to overtime and minimum wage protections.

\section{Challenges to the CoMPANionship EXeMPtion}

The companionship exemption has subsequently been challenged through multiple channels. While no Congressional proposals have yet been successful in amending the exemption, that has not stopped senators and representatives from offering proposed amendments. Other challenges have come from home care workers seeking FLSA protection through litigation, as well as through administrative rulemaking efforts. This section provides a brief summary of how the exemption has been challenged since 1975 .

1329 U.S.C. $\S 213(\mathrm{a})(15)(2016)$.

${ }^{14} I d$.

${ }^{15} I d$.

16 Extension to Domestic Service Employees, 40 Fed. Reg. 7404 (Feb. 20, 1975) (codified at 29 C.F.R. pts. 516, 552).

17 Id. at 7405 .

${ }^{18} I d$. 


\section{A. Legislative Challenges}

Most recently, efforts to amend the FLSA to cover home care workers have come in the form of proposed legislative amendments. In 2007, Representative Lynn Woolsey introduced the Fair Home Health Care Act in the House (House Bill 3582).19 The short bill defined "casual basis" domestic service employment as "irregular or intermittent" and provided that it is neither performed by an individual whose vocation is the provision of companionship services, nor may it exceed an aggregate twenty hours per week. ${ }^{20}$ Senator Tom Harkin introduced a similar bill in the Senate. ${ }^{21}$ Both bills were referred to committees, where they remained. ${ }^{22}$

Senator Robert Casey and Representative Linda Sanchez introduced the Direct Care Workforce Empowerment Act in 2010 where, again, the bills' primary purpose was limiting the companionship exemption by narrowing the scope of casual basis employment. ${ }^{23}$ Specifically, the bills would require casual employment to be "irregular or intermittent," and disallowed such employment from being performed by an individual in a vocational capacity. ${ }^{24}$ The bills further provided that "[e]mployment is not on a casual basis, whether performed for one or more family or household employers, if such employment for all such employers exceeds [twenty] hours per week in the aggregate." 25 The bills also directed the Secretary of Health and Human Services to create a data

${ }^{19}$ H.R. 3582, 110th Cong. § 2 (2007).

${ }^{20} I d . \S 2$.

21 S. 2061, 110th Cong. (2007). Notably, cosponsors of this bill included Senators Clinton and Obama. As will be discussed, the Clinton and Obama Administrations also attempted to limit the companionship exemption through administrative action.

22 H.R. 3582- Fair Home Health Care Act, Congress.gov, https://www.congress.gov/bill/110th-congress/house-bill/3582 (last visited Feb. 27, 2016); S.2061 -Fair Home Health Care Act of 2007 , CONGRESS.GOV, https://www.congress.gov/bill/110th-congress/senatebill/2061 (last visited Feb. 27, 2016).

${ }^{23}$ S. 3696, 111th Cong. (2010); H.R. 5902, 111th Cong. (2010).

${ }^{24}$ S. 3696, 111th Cong. (2010); H.R. 5902, 111th Cong. (2010).

25 S. 3696, 111th Cong. (2010); H.R. 5902, 111th Cong. (2010). 
collection and monitoring program, National Advisory Council on the Direct Care Workforce, and three-year grant program designed to improve recruitment, retention, and education of the direct care workforce. ${ }^{26}$ Neither bill made it out of committee. ${ }^{27}$

The following June, Senator Casey and Representative Sanchez tried again, introducing the Direct Care Job Quality Improvement Act of 2011 into their respective houses. ${ }^{28}$ These bills sought to clarify that the term "casual basis in domestic service employment to provide companionship services" means intermittent employment that is "not performed by an individual - (1) whose vocation is the provision of companionship services; or (2) who is employed by an employer or agency other than the family or household using their services." 29 In the event that a caregiver works for a family or individual more than five hours per week or for more than twelve weeks per year, the caregiver would not be considered to be working on a casual basis. ${ }^{30}$ In addition to FLSA amendments, the bills also called for the creation of a workforce monitoring program, a data sharing program, reports on the adequacy of long-term care support for Medicaid purposes, and multiple grant programs. ${ }^{31}$ Again, the bills were stuck after being referred to committee. ${ }^{32}$

In response to DOL's proposed narrowing of the companionship exemption, Representative Lee Terry introduced the Companionship Exemption Protection Act. ${ }^{33}$

${ }^{26}$ S. 3696, 111th Cong. (2010) §§ 4-5; H.R. 5902, 111th Cong. (2010) $\S \S 4-5$.

27 H.R. 5902- Direct Care Workforce Empowerment Act, CONGRESS.GOV, https://www.congress.gov/bill/111th-congress/housebill/5902 (last visited Feb. 27, 2016); S.3969 -Direct Care Workforce Empowerment Act, CoNGRESS.GOV, https://www.congress.gov/bill/111thcongress/senate-bill/3696/text (last visited Feb. 27, 2016).

${ }^{28}$ H.R. 2341, 112th Cong. (2011); S. 1273, 112th Cong. (2011).

${ }^{29}$ H.R. 2341, § 3 .

30 Id.; S. $1273, \S 3$.

${ }^{31} I d . \S \S 4-6 ;$ Id. $\S \S 4-6$.

32 H.R. 2341-Direct Care Job Quality Improvement Act of 2011, CONGRESS.GOV, https://www.congress.gov/bill/112th-congress/housebill/2341/text (last visited Feb. 27, 2016); S.1273-Direct Care Job Quality Improvement Act of 2011, CONGRESS.GOV, https://www.congress.gov/bill/ 112th-congress/senate-bill/1273/related-bills (last visited Feb. 27, 2016).

${ }^{33}$ H.R. 3066, 112th Cong. (2011). 
The Act proposed stripping the Secretary of Labor of the authority to define and delimit the exemption. ${ }^{34}$ A similar bill was introduced in the Senate by Senator Mike Johanns. ${ }^{35}$ Ultimately, neither was successful.

\section{B. Challenges through Litigation}

As individuals with disabilities began leaving institutions for group homes, ambiguity remained as to whether the companionship exemption applied to community-based settings that were not necessarily private homes (e.g., group homes owned by a provider and largely funded by the state). Even before the Supreme Court's seminal Olmstead decision, ${ }^{36}$ courts had begun providing greater clarity regarding the companionship exemption's applicability. One of the first cases to address the issue was Lott v. Rigby. ${ }^{37}$ There, house parents at Stephens County Independent Group Residence for the Mentally Retarded petitioned the court for overtime compensation. However, the court determined that the companionship exemption only applied to those services provided in a private home. ${ }^{38}$ Because the Residence was publicly funded, the house parents could not be domestic service employees. ${ }^{39}$

Numerous cases followed. In Linn v. Developmental Services of Tulsa, Inc., the court held that to determine whether a home was private, the court should focus on the elements of control, such as whether the service provider furnished the residence, maintained a set of keys, and paid rent, as well as whether residents were related and were offered a setting similar to an institution. ${ }^{40}$ In Madison $v$. Resources for Human Development, Inc., the court deemed the fact that clients did not live in the home prior to becoming clients of the service provider a significant factor in

\footnotetext{
${ }^{34} \mathrm{Id}$.

${ }^{35}$ S. 3280, 112th Cong. (2012).

${ }^{36}$ Olmstead v. L. C. ex rel. Zimring, 527 U.S. 581 (1999).

${ }^{37}$ Lott v. Rigby, 746 F. Supp. 1084 (N.D. Ga. 1990).

${ }^{38} I d$. at 1088 .

${ }^{39} \mathrm{Id}$.

40 See Linn v. Developmental Servs. of Tulsa, Inc., 891 F. Supp. 574 (N.D. Okla. 1995).
} 
determining whether the home was private. ${ }^{41}$ In Johnston $v$. Volunteers of America, Inc., the Tenth Circuit ruled that the employer bears the burden of proving that its employees meet the exemption. ${ }^{42}$

In 2004, the Tenth Circuit revisited the issue in Welding v. Bios Corp. 43 There, a group of caregivers for individuals with developmental disabilities in multiple homes alleged that their employer violated FLSA by improperly availing itself of the companionship exemption. The court determined that housing units are part of a "continuum," and "key inquiries" in determining where on that continuum the unit lies "are who has ultimate management control of the living unit and whether the living unit is maintained primarily to facilitate the provision of assistive services." 44 Factors to be addressed are: whether the recipient of care lived in the home prior to becoming a client of the provider; who owns the home, which "is significant because it evidences control"; who maintains the home by paying the mortgage, utilities, and food; whether the recipients of care would continue living in the home if you no longer received services from the provider; the difference in the relative values of services provided and the total cost of the living unit; and whether the provider uses any part of the home for business purposes. ${ }^{45}$ "[N]o single factor is dispositive, [though] some may be more important than others." 46 Two years later, the DOL adopted the Welding factors as its own. 47

A second area of litigation involving the companionship exemption challenged the notion that certain home care workers were untrained personnel. In McCune v. Oregon Senior Services Division, a group of live-in caregivers alleged that, as certified nursing assistants (CNAs), they met the

${ }^{41}$ See Madison v. Res. for Human Dev., Inc., 39 F. Supp.2d 542 (E.D. Pa. 1999). 2000).

42 See Johnston v. Volunteers of Am., Inc., 213 F.3d. 559 (10th Cir.

${ }^{43}$ Welding v. Bios Corp., 353 F.3d. 1214 (10th Cir. 2004).

${ }^{44} \mathrm{Id}$. at 1219.

${ }^{45} \mathrm{Id}$. at $1219-20$.

${ }^{46} \mathrm{Id}$. at 1219.

${ }^{47}$ Rebecca M. Fowler, Home Healthcare Workers and the Fair Labor Standards Act, 1 J. HEALTH \& LIFE SCI. L. 107, 122 (2008). 
companionship exemption exception for trained personnel. 48 The appellants had received 60 hours of training in order to achieve CNA certification. ${ }^{49}$ Appellants further requested that the court consider crediting them with additional training that had been received directly from the physicians of those receiving care..$^{50}$ Like the district court, the Ninth Circuit rejected this argument because, under Oregon law, the tasks that physicians trained the CNAs in were outside the scope of CNA competence and were instead the duties of a licensed nurse. ${ }^{51}$ The Court determined that it would be inappropriate to reward appellants for acting outside the scope of their authority. ${ }^{52}$ Moreover, it recognized that asking the State to account for on-the-job training and constantly reassess their employees for development would be "an administrative nightmare." 53

The Seventh Circuit faced a similar challenge from a home health aide in Cox v. Acme Health Services, Inc. ${ }^{44}$ The appellant had received 105 hours of training to become certified as a CNA, and completed additional training to achieve certification as a home health aide. ${ }^{55}$ Maintaining home health aide certification required a minimum of 12 hours continuing training each year. ${ }^{56}$ In bringing her claim for unpaid overtime wages, Cox argued "her training and duties as a home health aide were akin to the training and duties of a registered or practical nurse within the meaning of the exception to the FLSA's exemption for 'companionship services." 57 The Court opined that Cox had "received only a fraction of the training received by registered or practical

48 McCune v. Or. Senior Servs. Div., 894 F.2d 1107 (9th Cir. 1989). The group also alleged that because they provide general housekeeping services to clients, essentially performing the collective duties of cooks, maids, nurses, and other workers entitled to FLSA coverage, they, too, should be covered by the FLSA. Id. at 1109 .

49 Id. at 1113 .

50 Id. at 1111 .

${ }^{51} I d$.

${ }^{52} I d$.

${ }^{53} I d$.

${ }^{54}$ Cox v. Acme Health Servs. Inc., 55 F.3d 1304 (7th Cir. 1995).

55 Id. at 1307.

56 Id. at 1306.

${ }^{57} \mathrm{Id}$. at 1308. 
nurses."58 Additionally, the requirements for becoming a registered or practical nurse were more stringent, and included statutorily-mandated training in areas from biological sciences to nursing theory. 59 Although Cox had obtained training beyond the mandatory seventy-five hours necessary to be a home health aide in Indiana, it was "of no consequence" because the tasks she was performing did not require the additional training. ${ }^{60}$ The court held that to avail oneself of the trained personnel exception, "a domestic service employee must not only perform services requiring the training of a registered or practical nurse, but must in fact have obtained training comparable in scope and duration to that of a registered or practical nurse." 61

Only one case involving the companionship exemption made its way to the Supreme Court, Long Island Care at Home, Ltd. v. Coke.62 At issue was whether the DOL's regulation permitting third-party employers to avail themselves of the companionship exemption was valid. ${ }^{63}$ Coke was a caregiver that regularly worked seventy hours per week, ${ }^{64}$ and she sought minimum wages and overtime pay from her employer, a home care agency, and its owner. ${ }^{65}$ Coke argued that third-party employers should not benefit from the companionship exemption for three reasons.

First, Coke claimed that domestic service employment is an activity limited to those employed by the recipients of care. In support of her argument, Coke argued that the Social Security Act defines "domestic service employment" as activity conducted in the home of the employer. ${ }^{66}$ She further argued that domestic service workers used to be covered through enterprise coverage. ${ }^{67}$ The Court deemed this

\footnotetext{
${ }^{58}$ Id. at 1309.

59 Id. at 1310 .

${ }^{60} \mathrm{Id}$.

${ }^{61} I d$. (emphasis omitted).

${ }^{62}$ Long Island Care at Home, Ltd. v. Coke, 551 U.S. 158 (2007).

${ }^{63} \mathrm{Id}$. at 162.

${ }^{64}$ Elizabeth Riordan, Where the Heart Is: Amending the Fair Labor Standards Act to Provide Wage and Overtime Pay Protection to AgencyEmployed Home Health Aides, 85 ST. JoHN's L. REV. 837 (2011).

${ }_{65}$ Long Island Care at Home, Ltd., 551 U.S. at 164.

66 Id. at 166.

${ }^{67} \mathrm{Id}$. at 165 .
} 
argument unconvincing, noting that FLSA "expressly instructs the agency to work out the details of those broad definitions [of 'domestic service employment' and 'companionship services']. . . . [W] hether to include workers paid by third parties within the scope of the definitions is one of those details."68

Next, Coke argued that the plain language of the thirdparty regulation conflicts with the definition of "domestic service employment," in that the latter requires the worker to be in the home of the person by whom he or she is employed.69 The Court agreed that conflict exists, but determined that the third-party regulation governs. ${ }^{70}$ From a practical perspective, the Court did not believe it made sense for the exemption to hinge on whether the payor resided in the same household as the individual receiving care. If the conflict was resolved as Coke desired, then family members would not be able to avail themselves of the exemption if they lived in a different household than the individual receiving care. Such was not the intent of Congress. ${ }^{71}$ From a legal perspective, "normally the specific governs the general," meaning that the third-party regulation, the sole purpose of which is to address the issue of third-party payors, should trump the more general definitional regulation. ${ }^{72}$

Finally, Coke took issue with the way the regulation was promulgated. ${ }^{73}$ She argued that the third-party regulation was interpretive, and interpretive regulations cannot be used to bindingly fill a statutory gap, but are more appropriately deemed persuasive materials. ${ }^{74}$ However, the Court found this reasoning unconvincing. ${ }^{75}$ The DOL used formal notice and comment procedures, suggesting the regulation was meant to be as binding as any other. ${ }^{76}$ Moreover, the regulation was within the scope of the DOL's authority and

\footnotetext{
$68 \mathrm{Id}$. at 167.

${ }^{69} \mathrm{Id}$. at 168 .

${ }^{70} \mathrm{Id}$. at 169 .

${ }^{71} \mathrm{Id}$. at 170 .

${ }^{72} I d$.

${ }^{73}$ Id. at $171-72$.

${ }^{74} \mathrm{Id}$. at 172 .

$75 \mathrm{Id}$.

${ }^{76} \mathrm{Id}$. at 173.
} 
was reasonable. ${ }^{77}$ Coke argued that promulgation procedures were defective because notice and explanation of the regulation were inadequate. ${ }^{78}$ The Court found that DOL complied with its legal promulgation duties. ${ }^{79}$ Therefore, the new law of the land permitted third parties to avail themselves of the companionship exemption.

\section{Administrative Challenges}

In 1993, the first attempt to limit use of the companionship exemption was attempted by the Clinton Administration. ${ }^{80}$ Specifically, the DOL published its intent to forbid third-party employers from using the companionship and live-in exemption, except for those circumstances in which the employer had a joint employment relationship with the recipient of care. ${ }^{81}$ The rule was proposed as a mere clarification, based on the DOL's belief that the issue "may be susceptible of misinterpretation." 82

In 1995, the DOL reopened the comment period for those rules proposed in 1993.83 Although only seven comments were received in response to the 1993 notice of proposed rulemaking, they caused the DOL to consider the potential effect the proposed rule would have on state and local governments responsible for funding companionship services. ${ }^{84}$ Thus, the DOL specifically sought comments on permitting government entities, along with recipients of care and their family members, to avail themselves of the companionship exemption. ${ }^{85}$

77 Id.

$78 I d$. at 174 .

79 Id. at 175 .

80 Application of the Fair Labor Standards Act to Domestic Service, 58 Fed. Reg. 69,310 (Dec. 30, 1993) (to be codified at 29 C.F.R. pt. 552).

81 Id.

82 Id. at $69,311$.

83 Application of the Fair Labor Standards Act to Domestic Service, 60 Fed. Reg. 46,797 (Sept. 8, 1995) (to be codified at 29 C.F.R. pt. 552).

84 Id. at $46,797-98$.

85 Id. at 46,798 . 
A second, more comprehensive effort to amend the companionship exemption occurred in 2001.86 The notice of proposed rulemaking stated that the home care industry had experienced "significant changes" since 1975, such that home care workers were "performing types of duties and working in situations that were not envisioned when the companionship services regulations were promulgated." 87 Finding that the exemption no longer matched Congress's intent, the DOL again proposed excluding third-party employers from utilizing the companionship and live-in exemption. ${ }^{88}$ The DOL also proposed redefining "companionship services" and amending qualification criteria for "trained personnel." 89

The Bush Administration withdrew the proposed rule in 2002.90 The DOL under President Clinton stated that the proposed rule would not have a significant economic impact. 91 However, this assertion was "seriously called into question" by commenters, including the Small Business Administration and the Department of Health and Human Services. ${ }^{92}$

The companionship exemption remained untouched until 2011, when the Obama Administration decided to revive the Clinton proposals and introduce further amendments. As in 1993, the DOL cited changes in the home care industry, including "growing demand for long-term in-home care," the "rising cost of traditional institutional care," the "availability of funding assistance for in-home care under Medicare and Medicaid," and a "significant increase in our aging

${ }^{86}$ Application of the Fair Labor Standards Act to Domestic Service, 66 Fed. Reg. 5481 (Jan. 19, 2001) (to be codified at 29 C.F.R. pt. 552).

87 Id. at 5482 .

${ }^{88} \mathrm{Id}$. at 5485 .

${ }^{89} \mathrm{Id}$. at $5483-84$.

90 Application of the Fair Labor Standards Act to Domestic Service, 67 Fed. Reg. 16,668 (Apr. 8, 2002) (to be codified at 29 C.F.R. pt. 552).

${ }^{91}$ Application of the Fair Labor Standards Act to Domestic Service, 58 Fed. Reg. 69,310, 69,311 (Dec. 30, 1993) (to be codified at 29 C.F.R. pt. $552)$.

92 Application of the Fair Labor Standards Act to Domestic Service, 67 Fed. Reg. at 16,668. 
population." 93 According to the DOL, these factors contribute to a different workforce then that intended by Congress. ${ }^{94}$ Today's companions are often employed by third-party agencies rather than directly by the recipient of care, 95 and many of the companions rely on the job as their primary source of income. ${ }^{96}$ The DOL asserted that narrowing the companionship exemption would more accurately reflect congressional intent. 97

First, the DOL proposed broadening section 552.6, defining "companionship services," into four paragraphs..$^{98}$ Paragraph (a) defines "companionship services" as "the provision of fellowship and protection for a person who, because of advanced age or physical or mental infirmity, is unable to care for themselves," and goes on to define "fellowship" and "protection."99

Paragraph (b) provides that "companionship" includes the provision of care, so long as that care is incidental in nature. ${ }^{100}$ Incidental services constituting companionship, per the DOL, include using public transportation, going to appointments, and attending social events. ${ }^{101}$ Other services may be deemed incidental only after a fact-intensive inquiry. For example, the DOL expects that recipients of care can schedule their bathing routines to be outside of a companion's hours. ${ }^{102}$ Therefore, assisting a client with a bath or shower is outside the scope of companionship. However, if there is "an imminent need" for "cleansing," the DOL consider it "a reasonable but limited exception[" and permit assistance from a companion. ${ }^{103}$

93 Application of the Fair Labor Standards Act to Domestic Service, 76 Fed. Reg. 81,190, 81,190-91 (Dec. 27, 2011) (to be codified at 29 C.F.R. pt. 552).
${ }^{94} I d$. at 81,192 .
95 Id. at 81,193 .
96 Id. at 81,197 .
${ }_{97} I d$. at 81,192 .
${ }_{98} I d$.
${ }^{99} I d$. at 81,193 .
${ }^{100}$ Id. at 81,192 .
${ }^{101}$ Id. at 81,193 .
102 Id.
103 Id. 
Paragraph (c) further limits the scope of incidental duties, excluding "[g]eneral household work ... such as vacuuming, washing windows, and dusting" from the definition of companionship. 104 Because Congress offered FLSA protection to domestic service workers such as maids, the DOL believes tasks traditionally performed by these workers should not be included within a FLSA coverage exemption. ${ }^{105}$ As such, companions can no longer assist their clients with light housework.

Paragraph (d) eliminates from companionship services "medical care that is typically provided by personnel with specialized training." 106 The list of excluded activities is broad. Some tasks, such as blood sugar screening and the provision of physical therapy, clearly require training or direction. Yet other activities, such as "routine foot, skin, and back care" 107 appear to be just that-routine activities that require nothing more than common sense and an able body. Nevertheless, companions may not provide such assistance.

Further, the DOL eradicated the third-party companionship exemption for all parties, except "for the individual, family, or household" receiving care. ${ }^{108}$ This means that states and other government entities involved in funding homecare may be on the hook to pay minimum wage and overtime.

It is also important to note that individuals and families receiving care are not completely isolated from the rule's reach. Recall that the scope of "companionship services" was limited. 109 Thus, if a companion fails to qualify for the exemption and the individual or family receiving care can be considered a sole or joint employer, the individual or family will be required to pay minimum wage and overtime, regardless of any previously negotiated contract. If a recipient of care needs help going to the bathroom an extra time one day, this extra care could potentially trigger the 20 percent threshold and require that individual to pay

\footnotetext{
${ }^{104} I d$. at 81,195 .

$105 \mathrm{Id}$.

${ }^{106} I d$.

${ }_{107} I d$.

108 Id. at 81,198 .

109 See supra Section IC.
} 
minimum wage and overtime. If a recipient of care eats with a feeding tube, that individual will automatically be liable for minimum wage and overtime, as assisting him triggers the medically related services provision.

Finally, the DOL withdrew permission for live-in aides and employers to negotiate an employment contract in lieu of keeping a $\log$ of hours worked. ${ }^{110}$ In fact, the proposed regulation puts complete responsibility on the employer "for making, keeping, and preserving records of hours worked and ensuring the accuracy" thereof. ${ }^{111}$

\section{Home Care Association Challenge}

Despite the DOL "anticipat[ing] that the proposed rule will have relatively little effect on the provision of companionship services,"112 concerns were immediately raised by home care agencies and recipients of home care services. The Home Care Association of America, the International Franchise Association, and National Association for Home Care and Hospice quickly brought an action under the Administrative Procedures Act, arguing that the proposed rules constituted an arbitrary and capricious endeavor, clearly contrary to congressional intent and delegated authority. ${ }^{113}$ They requested an injunction, in order to continue utilizing the third-party provisions of the companionship exemption. ${ }^{114}$

The D.C. Circuit Court held that the regulations conflict with both the legislative history and plain language of the FLSA. ${ }^{115}$ In Step I of the Chevron analysis, the court must address whether Congress directly spoke to the question at issue. ${ }^{116}$ If the answer is "no", Chevron Step II requires the

110 Application of the Fair Labor Standards Act to Domestic Service, 76 Fed. Reg. at 81,198.

111 Id. at 81,199 .

112 Id. at 81,223 .

${ }^{113}$ Complaint for Declaratory and Injunctive Relief, Home Care Ass'n of Am. v. Weil, 76 F. Supp. 3d 138 (D.C. Cir. 2014) (No. 1:14-cv-00967).

114 Id.

${ }^{115}$ Home Care Ass'n of Am. v. Weil, 76 F. Supp. 3d 138, 147-48 (D.D.C. 2014), rev'd sub nom., 799 F.3d 1084 (D.C. Cir. 2015).

116 Id. at 143. 
court to determine whether Congress delegated authority to the executive agency to implement statute or fill a gap. ${ }^{117}$

Judge Leon found that "Congress surely did not delegate to the Department of Labor here the authority to issue a regulation that transforms defining statutory terms into drawing policy lines based on who cut the check rather than what work is being performed."118 Although Congress did leave some gaps to be filled by the DOL, including the definition of companionship services, once the "gaps were filled. . ., the statutory loop was closed."119 Ultimately, by implementing regulations that Congress declined to implement by statute, the DOL engaged in "yet another thinly-veiled effort to do through regulation what could not be done through legislation. Such conduct bespeaks an arrogance to not only disregard Congress's intent, but seize unprecedented authority to impose overtime and minimum wage obligations in defiance of the plain language of Section 213." 120

Once Leon vacated the third-party employment regulation, the trade associations gained standing. The associations petitioned for emergency injunctive relief to prevent the enforcement of the proposed regulations. The petition resulted in a memorandum decision from the DC Circuit Court, again written by Judge Leon.

In this second decision, Judge Leon found that while Congress did explicitly delegate to the DOL the power to define "companionship services," that delegation did "not grant it a blank check to do so in a way that contradicts the Act itself." 121 More specifically, the FLSA references companionship services in a way that makes clear such services are to be provided to individuals that cannot care for themselves. ${ }^{122}$ Yet, the DOL's proposed regulations remove that essential care from the definition. ${ }^{123}$ Congress revisited

${ }^{117}$ Id. at $143-44$.

118 Id. at 144 .

119 Id. at 145 .

${ }^{120} \mathrm{Id}$. at $147-48$.

${ }^{121}$ Home Care Ass'n. of Am. v. Weil, 78 F. Supp. 3d 123, 128 (D.D.C.), rev'd sub nom., 799 F.3d 1084 (D.C. Cir. 2015).

122 Id.

${ }_{123} I d$. 
the companionship provisions of the FLSA on numerous occasions since 1974, but never amended those provisions. ${ }^{124}$ Therefore, the DOL, in offering regulations on a topic in which Congress has already spoken and made its intent clear, acted outside the scope of its authority. ${ }^{125}$ The inquiry stops at Step I of the Chevron analysis. ${ }^{126}$

The DOL appealed, arguing that the Supreme Court's decision in Coke precludes the analysis ending at Step I. ${ }^{127}$ The U.S. Court of Appeals agreed. ${ }^{128}$ Judge Srinivasan opined that Coke placed within the DOL a "broad grant of authority" to decide whether companions employed by third parties fall within the scope of the companionship exemption. ${ }^{129}$ While the D.C. Circuit Court was incorrect to look to unpassed legislation as evidence of congressional intent, the Supreme Court already determined that, when it comes to the inclusion of third-party employers, "the full range of potential outcomes lay within the agency's discretion." 130

Home Care Association asserted that the DOL's interpretation was arbitrary, but the Court found that the proposed regulations were "entirely reasonable."131 Particularly, the DOL was attempting to bring FLSA protections to those employees "whose vocation is domestic service."132 Moreover, the court determined that the heightened standard Home Care Association wanted imposed with regard to a justification for reversing forty years of contrary interpretation was inappropriate. ${ }^{133}$ The DOL provided "a reasoned explanation" for limiting the exemption, which meets its legal burden. ${ }^{134}$

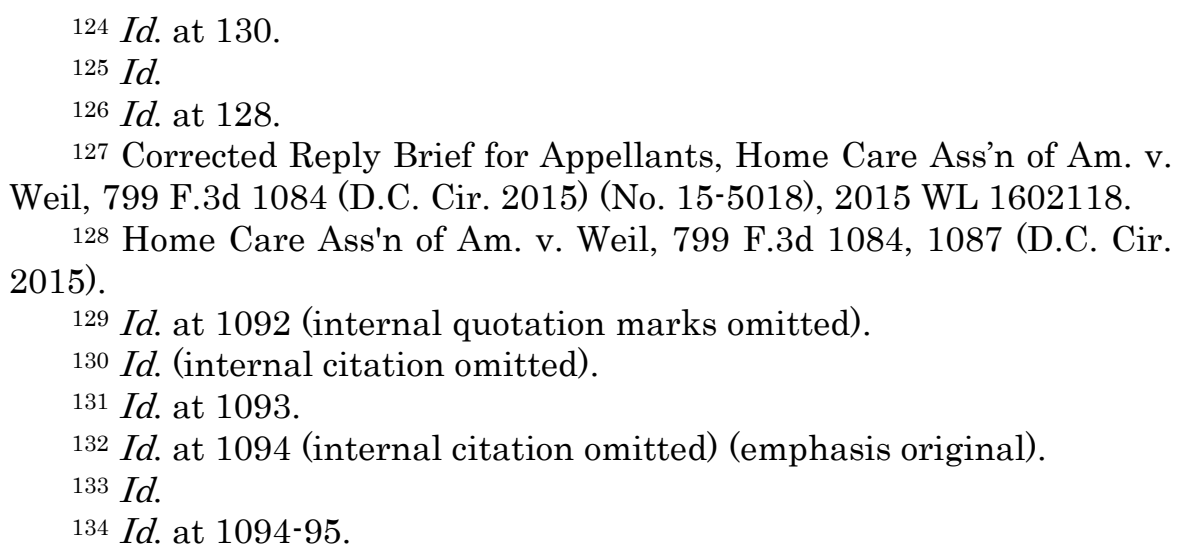


Ultimately, the court reversed and granted summary judgment to the DOL. 135 On September 24, 2015, the trade associations petitioned Supreme Court Chief Justice John Roberts to stay the rule, pending disposition of a petition for certiorari. ${ }^{136}$ Justice Roberts denied the petition on October 6,2015 .

\section{EFFECTS FOR RECIPIENTS OF CARE}

The 2010 census revealed that 56.7 million, or about one in five, people have a disability. ${ }^{137}$ More than half of them consider their disability to be severe. ${ }^{138}$ Almost 10 million noninstitutionalized people indicated the need for assistance with one or more activities of daily living. 139 These activities include tasks like dressing, toileting, and preparing meals. Thus, there is a great need for the services of home care workers. Indeed, given the reliance of people with disabilities on their caregivers, the home care rule has the potential to negatively affect them.

\section{A. Delivery of Services}

In order to understand how the home care rule will affect the quality and amount of care received by people with disabilities, it is necessary to examine the methods through which these services are delivered. Home care is funded through a variety of sources, including private pay by individuals and families and via government insurance programs. Approximately three-quarters of home care expenditures are paid by Medicare and Medicaid. ${ }^{140}$

135 Id. at 1097.

136 Application for a Stay of Mandate Pending the Timely Disposition of a Petition for a Writ of Certiorari, Home Care Ass'n of Am. v. Weil, 799 F.3d 1084 (D.C. Cir. 2015) (No. 15-A-326).

137 Nearly 1 in 5 People Have a Disability in the U.S., U.S. CEnsus BUREAU (July 25, 2012), https://www.census.gov/newsroom/releases/ archives/miscellaneous/cb12-134.html [http://perma.cc/FJ79-TRJT].

138 Id.

$139 \mathrm{Id}$.

140 Application of the Fair Labor Standards Act to Domestic Service, 76 Fed. Reg. 81,190, 81,223 (Dec. 27, 2011) (to be codified at 29 C.F.R. pt. 552). Medicaid funds the bulk of home care, paying for approximately 
Medicaid is not required to cover home health care, ${ }^{141}$ though most states have chosen to fund home care through a variety of methods. ${ }^{142}$

Traditionally, Medicaid beneficiaries receiving personal care in community settings have received services from a third-party home health agency that manages their care. ${ }^{143}$ Under this system, the agency is responsible for hiring and firing caregivers, seeking payment, and addressing any problems that arise. ${ }^{144}$ The state provides payment to the agency for this service.

In self-directed care programs, also known as consumerdirected care, the recipient of care is responsible for taking on many of the tasks historically performed by home care agencies. ${ }^{145}$ Payment of these caregivers depends on the type of system the state has adopted. ${ }^{146}$ Sometimes, the recipient of care is responsible for paying their caregiver and completing taxes. ${ }^{147}$ Other times, the state will contract with a fiscal intermediary that handles payroll and taxes. ${ }^{148}$ Regardless of the program's particulars, consumer-directed care is growing. Since 2001, almost all states have implemented at least one consumer-directed care program. ${ }^{149}$

$41 \%$ of the yearly home care expenditures. Medicare pays approximately $35 \%$ of these expenditures.

141 Medicaid Long-Term Care Services, U.S. DeP'T HeAlTh \& HuM. RESOURCES, http://longtermcare.gov/medicare-medicaid-more/medicaid /medicaid-long-term-care-services/ [http://perma.cc/64JJ-FD9N] (last visited Apr. 11, 2016). However, Medicaid is required to pay for care in institutional settings.

${ }^{142} \mathrm{Id}$.

143 Robert Newcomer et al., Consumer-Directed Personal Care: Comparing Aged and Non-Aged Adult Recipient Health-Related Outcomes Among Those With Paid Family Versus Non-Relative Providers, 30 Home Health Care Servs. Q. 178, 179 (2011).

${ }^{144} \mathrm{Id}$.

145 Teresa Scherzer et al., Financial Management Services in Consumer-Directed Programs, 26 Home Health Care Servs. Q. 29, 30 (2007).

${ }^{146} \mathrm{Id}$.

147 Id.

148 Id. at 33 .

$149 \mathrm{Id}$. at 30 . 


\section{B. State Implementation}

Many states are unprepared to comply with the new home care rule. Fiscal year budgets are already in place for 2016, and 2017 budgets are already well-developed in many states. ${ }^{150}$ This means that even if states were willing to bolster already-stretched Medicaid budgets, in order to cover the additional costs of minimum wage and overtime, it is too late. It is unlikely that agencies will be reimbursed beyond current Medicaid reimbursement rates for the foreseeable future. This means home health agencies will be required to eat the cost of the rule's new burdens or cease Medicaid participation.

The situation is even more complex for states offering Medicaid beneficiaries the opportunity to participate in consumer-directed services. States will be required to conduct an analysis to determine whether managed care organizations and fiscal intermediaries participating in these programs constitute a joint employment relationship. The DOL issued guidance on joint employment relationships, indicating that an economic realities analysis must be conducted. ${ }^{151}$ Elements of this analysis include "whether the potential employer has the power to hire and fire the employees, supervise and control the employees' work, determine the rate of payment, maintain employment records, and control where the work is performed." 152

\footnotetext{
150 Bazelon CENTER for Mental Health LaW ET AL., ACTion Steps FOR CONSUMERS AND ADVOCATES REGARDING THE DOL HOME CARE RULE: How to Prevent Service Cuts And Protect Consumer-Directed PROGRAMS 4-5 (2015), available at http://www.bazelon.org/ LinkClick.aspx?fileticket=u0RrEBo3adY\%3d\&tabid $=40 \quad$ [https:// perma.cc/JAP3-9FXQ].

151 Wage and Hour Division, Fact Sheet \#79E: Joint Employment in Domestic Service Employment Under the Fair Labor Standards Act (FLSA), U.S. Dept. of Labor, (last updated June 2014) https:// www.dol.gov/whd/regs/compliance/whdfs 79e.htm [https://perma.cc/96ZT8QKR].

152 Cindy Mann, CMCS Informational Bulletin: Self-DiReCtion PRogram Options For MEDICAID PAYMENTS IN THE IMPLEMENTATION OF The Fair Labor Standards ACt Regulation Changes 2 (2014), available at http://www.medicaid.gov/Federal-Policy-Guidance/ Downloads/CIB-07-03-2014.pdf.
} 
In the event that the relationship constitutes joint employment, a state must be vigilant not only of how many hours an employee works for each Medicaid beneficiary, but also whether the cumulative hours of each Medicaid beneficiary served by the employee will trigger minimum wage and overtime protection. Even if an employee provides caregiving services for less than 40 hours per week to multiple Medicaid beneficiaries, States must also calculate travel time between beneficiaries' homes and include it in the worker's hours. ${ }^{153}$

Given the parameters of existing budgets, states are trying to develop creative solutions for implementing the Rule. Unfortunately, these solutions may come at the expense of the recipients of care, as discussed in the sections below. The Department of Health and Human Services (DHHS) has released documents "strongly urg[ing] states to ensure that overtime or travel costs beyond an individual's control not be deducted from the individual's self-directed budget."154 That is, a recipient of care should not be forced to forgo services while a caregiver is driving to or from their home.

The DHHS and the Department of Justice also released a joint "Dear Colleague Letter" reminding states of their obligation under Title II of the Americans with Disabilities Act (ADA) to provide those services that permit individual with disabilities to live in the least restrictive environment. ${ }^{155}$ In particular, the agencies recognized that states are planning to put a 40-hour cap on the amount of services that can be provided by any given worker. They warned that "implementation of across-the-board caps risks violating the $\mathrm{ADA}$ if the caps do not account for the needs of individuals with disabilities and consequently places them at serious risk of institutionalization or segregation." 156

153 See Application of the Fair Labor Standards Act to Domestic Service, 76 Fed. Reg. 81,190, 81,219 (Dec. 27, 2011) (to be codified at 29 C.F.R. pt. 552).

154 MANN, supra note 153 , at 3.

155 Vanita Gupta \& Jocelyn Samuels, Olmstead Dear Colleague Letter on FLSA Home Care Rule, DeP’T Health \& Hum. SERvs. (Dec. 15, 2014), http://www.hhs.gov/sites/default/files/2014hhsdojdearcolleagueletter.pdf [http://perma.cc/MC2P-WG69].

${ }_{156} I d$. at 3. 
Nevertheless, states will be faced with difficult choices. Unfortunately, institutionalization, as well as increased safety risks, appear to be very real natural consequences of the rule's implementation at the state level. ${ }^{157}$

\section{Harms to Recipients of Care}

From the beginning, the DOL has failed to recognize the magnitude of the changes it has mandated. The notice of proposed rulemaking anticipated "that the proposed rule will have relatively little effect on the provision of companionship services." 158 Yet, it admits that there is "almost no data . . . that can directly be used to model the market for companionship services."159 Additionally, "[d]ue to the sometimes informal nature of the consumer-directed employment arrangements, there are no data on the total number of customers under this model, and there is limited information on the total number of providers." 160

Instead of conducting a thorough market analysis, the DOL concluded that, because 14 states currently provide some type of minimum wage or overtime protection to companions, "objections raised in the past regarding the feasibility and expense of prohibiting third parties from claiming the companionship and live-in worker exemptions" are negated. ${ }^{161}$ This fact is misleading because not all fourteen states provide the complete protection mandated under the new rule. ${ }^{162}$ It also ignores the fact that those

157 This is especially ironic considering that the expenses of Olmstead litigation, and even institutionalized care itself, are greater financial burdens for states than the provision of a good home- and communitybased care system. See Charlene Harrington et al., Do Medicaid Home and Community Based Service Waivers Save Money?, 30 Home HeAlth CARE SERVs. Q. 198, 210 (2011).

158 Application of the Fair Labor Standards Act to Domestic Service, 76 Fed. Reg. at 81,223.

${ }^{159} \mathrm{Id}$.

${ }^{160}$ Id. at 81,208 .

161 Id. at 81,197. These states are: Colorado, Hawaii, Illinois, Maryland, Massachusetts, Michigan, Minnesota, Montana, Nevada, New Jersey, New York, Pennsylvania, Washington, and Wisconsin.

${ }_{162}$ Id. at 81,204-06. 
states chose to implement the protections, and consequently had the opportunity prepare for implementation. ${ }^{163}$

The DOL, while perhaps not aware of the severity of changes, was aware that home care agencies will need to make significant changes in order to comply with the new regulation. It offered three operational choices to these agencies:

First, the agency might manage existing staff to reduce overtime hours while managing the same caseload and staffing levels.... Second, as suggested in the City of New York's amicus brief, agencies might choose not to allow staff to exceed 40 hours per week. ... The third scenario comprises a mix of the first and second approach. Neither of those approaches is costless to agencies, therefore, agencies will weigh the costs of hiring additional workers with the cost of paying overtime to existing workers to determine the optimal mix of overtime a new hires approximate to their circumstances. 164

Easier said than done.

In an amici brief, multiple States argued that "the operational viability" of the Medicaid program has been threatened, "both in letter and spirit."165 How have states reacted thus far? By the time ADAPT and the National Council on Independent Living submitted their joint brief, Arkansas had proposed placing a forty-hour per week cap on

163 DOL did not release FACT SHEET \#79E, regarding the homecare rule's effect on States, until June 2014. See U.S. DEP'T OF LABOR, FACT SHEET \#79E: JoINT EMPloyment IN DOMESTIC SERVICE EMPlOymENT UNDER THE FAIR LABOR STANDARDS ACT (FLSA) (2014), available at http://www.dol.gov/whd/regs/compliance/whdfs79e.pdf.

${ }^{164}$ Application of the Fair Labor Standards Act to Domestic Service, 76 Fed. Reg. at 81,218.

${ }^{165}$ Brief of the States of Kansas, Arizona, Georgia, Michigan, Nevada, North Dakota, Tennessee, Texas and Wisconsin in Support of Affirming the District Court at 2, Home Care Ass'n of Am. v. Weil, 799 F.3d 1084 (D.C. Cir. 2015) (No. 15-5018), 2015 WL 1534373, at *2. 
companionship hours. 166 Virginia proposed a fifty-six hour cap and requiring providers of companionship services to have a single employer. 167 Illinois, Massachusetts, New Mexico, and New York-a few of the states the DOL looks to as proof that the home care rule will be effective-openly acknowledge capping hours. 168

Individuals receiving care will not simply stop needing to go to the bathroom after receiving 40 hours of care. Ratherand assuming they are provided the extra assistance-these individuals will have to invite more strangers into their homes. As disability rights activists maintain: "[p]ersonal autonomy and bodily integrity are fundamental human rights. Our courts have upheld these rights in a variety of situations where others have sought to regulate an individual's body."169 Likewise, laws against assault and battery "protect individuals from experiencing unwanted touching from another person. However, under the new rule, disabled people will be forced to allow unwanted touching by new attendants if they want to live in the community." 170

Legal scholars brush over this argument. Molly Biklen writes, "[t]he commodification of caregiving and the growth of the home healthcare industry suggest that there is no longer a core of intimate personal services to be protected by an exemption." 171 Tell that to the elderly woman who needs help cleaning up after she could not quite make it to the restroom on time. Tell the transgendered man who needs assistance changing his clothes that it is no big deal who sees his surgical scars. ${ }^{172}$ Try keeping a straight face, knowing

166 Corrected Brief for ADAPT and the National Council on Independent Living as Amici Curiae Supporting Appellees at 10, Home Care Ass'n of Am. v. Weil, 799 F.3d 1084 (D.C. Cir. 2015) (No. 15-5018), 2015 WL 1534374 , at *10.

167 Id. at 11.

$168 \mathrm{Id}$.

$169 \mathrm{Id}$. at 22.

170 Id. at 25 .

171 Molly Biklen, Healthcare in the Home: Reexamining the Companionship Services Exemption to the Fair Labor Standards Act, 35 Colum. Hum. RTs. L. REV. 113, 150 (2003).

172 See Corrected Brief for ADAPT and the National Council on Independent Living as Amici Curiae Supporting Appellees, supra note 162 , at $23-24$. 
that individuals with disabilities have a dramatically higher rate of suffering violent crime than non-disabled individuals. ${ }^{173}$

Lack of respecting one's preference is a particularly salient issue for participants in consumer-directed care programs. People choose to participate in such programs for the very purpose of controlling their care. As New York's Consumer Directed Personal Assistance Program (CDPAP) attempted to persuade in its amicus brief:

The CDPAP is the gem of the Medicaid program. It is quintessentially American. It is about liberty. In the CDPAP, the individual, not the agency, decides when to get up, when to take a bath, when to get dressed, and when to go to bed. The individual decides who to let into his or her own home. The individual decides how services are delivered. The individual decides who can touch his or her body. The individual is in charge of his or her own life. ${ }^{174}$

If a fiscal intermediary is forced to cap caregiver hours under the new rule, participants will lose vital autonomy.

In certain situations, individuals may lose caregivers altogether. Consider Arkansas again, which has considered forbidding caregivers from serving more than one client with a disability. ${ }^{175}$ These caregivers, in order to make a living, are going to seek out those clients that need a number of

173 Violent Crime Rate in 2013 Against Persons with Disabilities was More than Double the Age-Adjusted Rate for Persons without Disabilities, BuREau OF Justice Statistics (May 21, 2015, 10:00 AM), http://ojp.gov/newsroom/pressreleases/2015/ojpapr05212015.pdf [http://perma.cc/7K5U-PFET].

174 Amicus Curiae Brief of the Consumer Directed Personal Assistance Association of New York State Submitted in Support of the Plaintiffs/Appellees at 10, Home Care Ass'n of Am. v. Weil, 799 F.3d 1084 (D.C. Cir. 2015) (No. 15-5018), 2015 WL 1544793, at *10.

175 Corrected Brief for ADAPT and the National Council on Independent Living as Amici Curiae Supporting Appellees, supra note 162 , at 18. 
hours of service as close to the maximum as possible. ${ }^{176}$ Yet many people with disabilities only need-or have only been approved for-as few as two or three hours of service per day. Services received during these hours are often crucial, entailing, for example, getting out of bed in the morning or getting transported to work. But, unless these individuals find caregivers willing to earn minimum wage for fifteen hours per week, they may be stuck in bed.177

The DOL answered advocates' concerns by advancing the position that continuity of care is already diminished because "low wages, poor or nonexistent benefits, and erratic and unpredictable hours" result in high caregiver turnover. ${ }^{178}$ It claims that, in some locations, the turnover rate is $100 \% .{ }^{179}$ These extreme statistics are questionable on their face. Disability advocacy groups furthermore recognize that, in gathering turnover rate data, the DOL combined post-acute, long-term, and consumer-directed care statistics. 180 This amalgam is improper because post-acute care is, by its nature, not designed to be sustained. ${ }^{181}$

Regardless of whether continuity of care is already poor, the home care rule threatens to exacerbate the problem. Kansas told the court that it has a shortage of home care workers available in its rural communities. ${ }^{182}$ Other states lack a sufficient number of caregivers to assist recipients of care for whom spoken English is not the primary language. ${ }^{183}$ Individuals requiring care in these situations are already at

176 Presumably, this maximum will be 40 hours per week.

177 Or, of course, get forced into an institution.

178 Application of the Fair Labor Standards Act to Domestic Service, 76 Fed. Reg. 81,190, 81,229 (Dec. 27, 2011) (to be codified at 29 C.F.R. pt. $552)$.

$179 \mathrm{Id}$.

180 Corrected Brief for ADAPT and the National Council on Independent Living as Amici Curiae Supporting Appellees, supra note 162 , at 17.

${ }^{181} \mathrm{Id}$.

182 Brief for the States of Kansas, Arizona, Georgia, Michigan, Nevada, North Dakota, Tennessee, Texas and Wisconsin at 4, Home Care Association of Am. v. Weil, 799 F.3d 1084 23, (D.C. Cir. 2015) (No. 155018).

183 Corrected Brief for ADAPT and the National Council on Independent Living as Amici Curiae Supporting Appellees, supra note 162 , at 20 . 
extreme risk of being institutionalized. Limiting the pool of available care by placing a limit on the number of hours that each caregiver may work is dangerous for people who need the care and is also against the interests of the caregivers themselves.

\section{CONSEQUENCES For HOME CARE WORKERS}

The home care rule was promulgated for the benefit of those who have devoted their career to caregiving. The DOL cited "significant changes in the home health care industry over the last 35 years" as justification for the amendments. ${ }^{184}$ Advocates for the inclusion of domestic service workers into FLSA's protective fold argue that the work is "at the very least, thankless," and, at best, "despised and low class." 185 By offering caregivers FLSA protection, by recognizing their job duties as valuable, and by treating them like other professionals, advocates argue, caregiver status is improved. But is this actually the case?

Both the DOL and labor advocates fail to recognize the role of the caregiver as unique. Caregivers are valued by those for whom they care. Indeed, without assistance from a caregiver, many individuals with disabilities would not be able to get out of bed in the morning. That an individual with a disability is so dependent upon a caregiver to provide necessary assistance with intimate activities of daily living creates a relationship beyond the typical employer-employee exchange. Caregivers do more than assist their employers routine job duties; instead, they assist them in living life. It is crucial that any regulations affecting home care take this dynamic into account.

Moreover, although the home care rule may sound good to some labor advocates in theory, the regulations do not guarantee that caregivers will actually receive higher wages. As discussed in Part III, the DOL actually provides employers with workarounds to avoid paying caregivers

${ }^{184}$ Application of the Fair Labor Standards Act to Domestic Service, 76 Fed. Reg. at 81,190.

185 Lisa Diaz-Ordaz, Real Work: Domestic Workers' Exclusion from the Protections of Labor Laws, 19 BUfF. J. GENDER L. \& Soc. PoL'Y 10708 (2001). 
increased wages. ${ }^{186}$ Lessons from states currently attempting to implement the home care rule demonstrate that caregivers may actually have decreased wages and autonomy, as explored in Section B.

\section{A. Home Care Worker Representation}

It is not evident why the Obama Administration believed amending the regulations was appropriate. Although it cited a growing demand for care, as well as increased government funding, the DOL failed to make a case that the actual nature of home care has changed. As Congress members opposing the changes noted,

[w]e may have made many technological advances ... but no one has yet found a viable everyday substitute for eating, dressing, or bathing. An elderly or infirm person incapable of caring for himself or herself in 1974 needed the same type of assistance that ... person needs today. ${ }^{187}$

Instead, the motivation for the rule appears political; supporters have certainly cast it in such terms. Secretary Perez stated: "The pie is growing; American workers helped bake it, but most of them aren't getting a bigger slice."188 Scholars refer to the companionship exemption as

186 Application of the Fair Labor Standards Act to Domestic Service, 76 Fed. Reg. at 81,218.

187 Brief for Amici Curiae Members of Congress at 20, Home Care Ass'n of Am. v. Weil, 799 F.3d 1084 (D.C. Cir. 2015) (No. 15-5018). Those represented by the brief include Senators Mitch McConnell, Pat Roberts, Lamar Alexander, Roy Blunt, John Boozman, Mike Enzi, Johnny Isakson, and Marco Rubio, as well as Representatives Tim Walberg and Lynn Jenkins.

188 Thomas E. Perez, The Fair Labor Standards Act at Seventy-Seven: Still "Far-Reaching, Far-Sighted", 30 ABA J. LAB. \& EMP. L. 299, 300 (2015). 
"shortchanging workers," 189 promoting "a legal fiction,"190 or a codification of "the legacy of slavery."191

It is true that many home care workers fit within at least one category typically viewed as marginalized. Per DOL statistics, the average caregiver is a female in her mid-40s. ${ }^{192}$ There is approximately a $40 \%$ chance that she is AfricanAmerican or Hispanic, and, in some regions, a fair chance that she is foreign-born. ${ }^{193}$ These statistics also mean there is a great chance that many of these caregivers voted for Obama.194 Indeed, the Service Employees International Union (SEIU) was a top contributor to the Obama campaign, raising more money for Democratic candidates in 2012 then Obama's biggest political action committee. ${ }^{195}$

189 Julia Lippitt, Protecting the Protectors: A Call for Fair Working Conditions for Home Health Care Workers, 19 ELDER L.J. 219, 236 (2011).

190 Biklen, supra note 167 , at 146.

191 Brief of Women's Rights, Civil Rights, and Human Rights Organizations and Scholars as Amici Curiae in Support of DefendantsAppellants Seeking Reversal at 5, Home Care Ass'n of Am. v. Weil, 799 F.3d 1084 (D.C. Cir. 2015) (No. 15-5018). Those represented by the brief include the American Civil Liberties Union, the Asian American Legal Defense and Education Fund, Eileen Boris, Jennifer Klein, Students in the Health and Human Rights Clinic at Indiana University McKinney School of Law, Latina/Latino Critical Legal Theory, Inc., National Law Center on Homelessness and Poverty, National Center for Law and Economic Justice, National Council of La Raza, National Hispanic Leadership Agenda, National Women's Law Center, Northwest Arkansas Workers' Justice Center, Santa Clara University School of Law International Human Rights Clinic, the U.S. Human Rights Network, Frank Askin, Karl Klare, William P. Quigley, and Deborah M. Weissman.

192 Application of the Fair Labor Standards Act to Domestic Service, 76 Fed. Reg. 81,190, 81,211 (Dec. 27, 2011) (to be codified at 29 C.F.R. pt. 552 ).

${ }_{193} I d$. at 81,212 .

194 United States Elections: How Groups Voted in 2012, ROPER CENTER., http://ropercenter.cornell.edu/polls/us-elections/how-groupsvoted/how-groups-voted-2012/ [http://perma.cc/9TQQ-P5W9] (last visited Apr. 11, 2016).

195 Melanie Trottman \& Brody Mullins, Union is Top Spender for Democrats, WALL ST. J., http://www.wsj.com/articles/ SB10001424052970204707104578091030386721670 [http://perma.cc/ 2FLZ-J9B5] (last updated Nov. 1, 2012). 
Home care workers began organizing in the mid-1980s. ${ }^{196}$ The first states to organize were Oregon, Washington, Illinois, and Massachusetts. ${ }^{197}$ Maryland, Missouri, Connecticut, Vermont, and Minnesota were next. ${ }^{198}$ Through collective bargaining, home care workers in these states were able to negotiate some combination of healthcare, training, paid time off, grievance procedures, transportation, and benefits. ${ }^{199}$ For example, in some California counties, a home care worker receives healthcare, training, free use of public transportation, and the opportunity to grieve about adverse employment determinations. ${ }^{200}$

However, these benefits come with a cost, sometimes to the recipient of care. The demands of organized labor are often at odds with the consumer-directed care model. Not only does an individual receiving care need to work with strangers in completing activities of daily living, but, in organized states, they are forced to invite yet another strange party into their private sphere. Each additional group that receives a voice in the care delivery discussion diminishes autonomy available to the recipient of care.

Although the SEIU may believe caregivers should have the right to appeal terminations, that means individuals receiving care may be stuck working with a caregiver that was terminated for an egregious error. Perhaps an omission caused the caregiver to injure her client. Surely, the injured party should not be forced to maintain such a dangerous situation. Granted, a consumer-directed care employer may terminate a caregiver for reasons unrelated to poor conduct, and possibly even for reasons over which the caregiver has no fault. But, recall that the recipient of care needs to feel comfortable with the individual assisting him or her with the most personal of tasks.

196 SEIU Local 503, Overview of Homecare Collective Bargaining, SEIU LOCAL 503.ORG (Dec. 13, 2013), http://www.seiu503.org/ 2013/12/overview-of-homecare-collective-bargaining/ [http://perma.cc/ GM9W-NAWX].

${ }_{197} I d$.

198 Id.

${ }^{199} I d$.

$200 I d$. 
Similarly, labor scholar Peggie Smith complains that the Occupational Safety and Health Act does not adequately protect employees engaged in the provision of consumerdirected care. ${ }^{201}$ She argues that home care workers have "no protection from various hazards including dangerous household objects, exposure to blood or other infectious material, and injuries occasioned by lifting and moving clients."202 Yet going into homes and touching disabled, elderly, and potentially ailing bodies are essential functions of home care work. Smith appears to prefer that homes be treated as office buildings, and that clients subscribe to a strict union-approved protocol. Whether or not a Hoyer lift is a pain in the butt-or literally causes pain-for recipients of care is inconsequential, as long as protocols are in place.

Union activity also has costs for employees. Part of this cost comes from the collection of dues. Until the Supreme Court issued its 2014 decision in Harris v. Quinn, unions were collecting fair share dues from caregivers that had no desire to join. ${ }^{203}$ In less than 18 months, approximately 30,000 home care workers ended their membership in SEIU Healthcare Illinois, Indiana, Missouri, and Kansas. ${ }^{204}$ This mass exodus from the union's rolls suggests that perhaps SEIU was not speaking for most home care workers.

Indeed, union contracts have cost some home care workers wage-earning hours. In early 2015, SEIU negotiated with the State of Minnesota to set a $\$ 10.75$ minimum wage for personal care attendants. ${ }^{205}$ Minnesota resident Scott Price explained that he would have to cut back hours of care

201 Peggie R. Smith, Home Sweet Home? Workplace Casualties of Consumer-Directed Home Care for the Elderly, 21 NotRE DAME J.L. ETHICS \& PUB. POL’Y 537, 549-50 (2007).

202 Id. at 550.

${ }^{203}$ Harris v. Quinn, 134 S. Ct. 2618 (2014).

204 Sean Higgins, Caregivers Leave Midwest Union in Droves One Year After Harris v. Quinn, WASH. EXAMInER (Nov. 1, 2015, 1:01 AM), http://www.washingtonexaminer.com/caregivers-leave-midwest-unionin-droves-one-year-after-harris-v.-quinn/article/2575406 [http:// perma.cc/6TGY-2V77].

205 J. Patrick Coolican, SEIU Contract Kicks in for 27,000 Home Care Aides in Minnesota, STAR TRIB. (June 30, 2015, 11:06 PM), http://www.startribune.com/seiu-contract-kicks-in-for-27-000-homecare-aides-in-state/311086561/ [http://perma.cc/XP24-G4SY]. 
received by his daughter, a 23-year-old with cerebral palsy, because he could not afford to pay the higher minimum wage for those hours she was asleep. ${ }^{206}$ As he explained, "The burden falls back on the family in terms of caring for a child with a disability[.]"207 The Prices are not alone; few families are in a position to afford the $\$ 94,170$ price tag that now comes with a year of 24-hour care in Minnesota.

The situation in Minnesota is illuminating for two reasons. First, as Mr. Price states, despite claims about increased professionalization of the caregiving workforce, much of the responsibility for caregiving falls to family members. ${ }^{208}$ Some of this care is unpaid. However, consumer-directed care provides a unique opportunity for family members to receive payment for caring for a loved one with a disability. The DOL, for example, notes that California "has a high percentage of caregivers who are paid family members." 209 In Michigan, approximately half of the independent providers are related to recipients of care. ${ }^{210}$

That many caregivers are related to their employer diminishes the validity of accusations that these workers are treated deplorably. It also means that many of these workers feel intruded upon by increased regulatory and professional oversight, just as their employers do. They do not want union members to come to their homes and conduct inspections. ${ }^{211}$ Nor are such workers interested in being trained regarding the care of a loved one. ${ }^{212}$ Additionally, many of these

206 Id.

207 Id.

$208 I d$.

209 Application of the Fair Labor Standards Act to Domestic Service, 76 Fed. Reg. 81,190, 81,212 (Dec. 27, 2011) (to be codified at 29 C.F.R. pt. 552).

210 Pamela Doty et al., Consumer Choice and the Frontline Worker, 18 GENERATIONS 65 (1994), available at http://aspe.hhs.gov/sites/ default/files/pdf/73936/frntlnwk.pdf [http://perma.cc/L65E-CLL4].

211 Sean Higgins, Big Labor Trickery on Display in Effort to Unionize

Home Care, WASH. EXAMINER (Oct. 31, 2015, 12:01 AM), http://www.washingtonexaminer.com/big-labor-trickery-on-display-in-

effort-to-unionize-home-care/article/2575302 [http://perma.cc/4B7ECQFN].

212 Paul Kersey, Union Recruiters Have Been Relentless in Making Sure that Caregivers Get to Hear the Union Pitch, ILL. POL'Y (Nov. 18, 
workers are not interested in having their personal information divulged to third parties, per union directives. ${ }^{213}$

Second, as illustrated by the Prices, many employers lack the resources to continue paying caregivers for the same amount of hours if wages are increased. While the care that is received by people with disabilities is often essential, the realities of today's economy mean that demand is not unceasingly elastic. Sometimes families, like the Prices, will provide uncompensated care themselves. Others will not have this capacity, leaving the person in need of care to simply suffer without it. Either way, the home care worker loses the ability to earn a portion of income previously attained.

Thus, while unions have played an increasing role in home care over the preceding decades, this involvement has not been unanimously embraced. Union victories have sometimes been championed at the expense of workers. The home care rule, which can be construed as another union victory, similarly brings negative consequences for the workers who have been heralded as its beneficiaries.

\section{B. Pragmatic Effects for Home Care Workers}

Certainly, the DOL is correct to recognize that caregiving is an important job and caregivers deserve decent wages. As discussed, caregivers enable people with disabilities to perform activities of daily living. This, in turn, enables people with disabilities to contribute to their communities through community engagement, employment, and family life. Although this author is unwilling to describe home care work as necessarily "strenuous" 214 or "physically demanding

2014), http://www.illinoispolicy.org/proposed-law-force-parents-attendunion-led-training/ [http://perma.cc/VDT4-SH54].

${ }^{213}$ Mike Dennison, Governor, Union Want In-Home Health Worker Info Public; Bill Would Keep it Private, Missoulian (Apr. 9. 2015), http://missoulian.com/business/local/governor-union-want-in-homehealth-worker-info-public-bill/article_d77a143a-d327-5b10-b9dba749e3b25ecc.html [http://perma.cc/CY4Z-UQZK].

214 Brief of Women's Rights, Civil Rights, and Human Rights Organizations and Scholars as Amici Curiae in Support of DefendantsAppellants Seeking Reversal supra note 187, at 22. 
and emotionally draining," 215 it does take patience, diligence, and compassion. Not everyone can succeed as a caregiver, but those that do should receive fair compensation.

Unfortunately, those providing home care services are often paid too little. In 2015, the median pay rate for a home health aide was $\$ 10.54 .^{216}$ A personal care aide could expect to receive even less, on average, with a 2015 median hourly pay rate of $\$ 10.09$ per hour. ${ }^{217}$ In promulgating the home care rule, the DOL specifically looked at these two occupational categories and stated that the low income associated with these jobs is problematic. ${ }^{218}$ Nevertheless, it is not clear that the home care rule will actually benefit these employees.

However, the DOL recognizes "very few [home care workers] work overtime" when employed by agencies. ${ }^{219}$ Thus, few stand to benefit from the new overtime provisions. Even so, the few workers who may be eligible for overtime under the new regulations are unlikely to receive it. The DOL actually notes: "there is no reason to believe the agencies will simply continue current staffing patterns and pay workers overtime for any hours exceeding 40 per week." 220 Instead, agencies will cut hours, potentially reducing the total income home care workers received under the previous regulations. In fact, in the notice of proposed rulemaking, the DOL offers agencies the option to "choose not to allow staff to exceed 40 work hours per week." 221

215 Peggie R. Smith, Aging and Caring in the Home: Regulating Paid Domesticity in the Twenty-First Century, 92 Iowa L. Rev. 1835, 1849 (2007).

216 Occupational Outlook Handbook, BUREAU OF LABOR STATISTICS (Dec. 17, 2015), http://www.bls.gov/ooh/healthcare/home-healthaides.htm [http://perma.cc/JXV3-FTT6].

217 Id.

218 Application of the Fair Labor Standards Act to Domestic Service, 76 Fed. Reg. 81,192, 81,212 (Dec. 27, 2011) (to be codified at 29 C.F.R. pt. 552 ).

219 Id. at 81,213. The DOL further admits that it does not have particularly robust or reliable information regarding how employees provide services through consumer-directed care employment relationships. Id. at 81,208 .

220 Id. at 81,220 .

${ }^{221} \mathrm{Id}$. at 81,218 . 
Trapped in pre-allocated budgets, and unwilling to take on the administrative burden of more closely managing the hours of each home care worker, states are planning to implement similar, and sometimes more draconian, measures. Arkansas not only proposed a forty-hour weekly cap on the number of hours an attendant care worker may work each week, but also proposed limiting workers to providing assistance for only one Medicaid beneficiary. ${ }^{222}$ If a caregiver works forty hours a week with multiple clients (e.g., ten hours each week with John and thirty hours each week with Nancy), she will need to choose which client with which she wants to continue working. No matter her choice, she faces a reduction in total hours worked. Unless she can find a private pay client, she also likely faces a reduction in income.

Ohio proposed eliminating its independent provider program entirely. ${ }^{223}$ The proposal would require over 13,000 home care workers to find work with a home care agency in order to continue providing services. ${ }^{224}$ In addition to being detrimental to recipients of care, the elimination of the independent provider program is also injurious to providers. Caregivers would be required to find new jobs. Even if a caregiver manages to get hired by the agency that serves her current clients, she no longer works directly with them, but must be supervised by an agency middleman.

Indeed, serving as an independent provider offers caregivers the opportunity to partake in benefits that the traditional agency model does not offer. Consider that $85 \%$ of workers in consumer-directed care programs felt as though

222 Arkansas Department of Human Services Division of Medical Services, Alternatives for Adults with Physical Disabilities Waiver (Oct. 31, 2014), http://170.94.37.152/REGS/016.06.14-026P-14580.pdf [http:// perma.cc/L63M-M4GS].

223 Governor Proposes Changes Affecting Independent Providers of Home Care, Disability Rights OHIO (Mar. 5, 2015), http:// www.disabilityrightsohio.org/news/governor-proposes-changes-affectingindependent-providers-home-care [http://perma.cc/3AAB-5235].

${ }_{224}$ Gov. John Kasich's Budget to Phase Out Independent Health Worker Option, OHIO.COM, http://www.ohio.com/news/break-news/govjohn-kasich-s-budget-to-phase-out-independent-health-worker-option1.565510 [http://perma.cc/FY4A-53TZ] (last updated Feb. 10, 2015, 1:29 PM). 
they had close relationships with their employers, while only $55 \%$ of caregivers from agencies felt close to the recipients of their care. ${ }^{225}$ Additionally, despite the poor pay, "about 45\% of directly hired workers reported being very satisfied with their wages and benefits. . . . In contrast, $22 \%$ of agency workers report being very satisfied . ..."226 As such, there is evidence that working outside of the agency model offers caregivers increased job satisfaction and overall well-being. The new regulations jeopardize the continuance of these agreeable conditions, and fail to recognize that a job is more than a mere paycheck.

Nonetheless, it is critical to note that the paychecks of some independent caregivers may also be completely at risk. Other states are exploring whether it is appropriate to maintain consumer-directed care programs in the wake of the new rule. ${ }^{227}$ Over 800,000 participants may be affected. ${ }^{228}$ Of the participating providers, many are family members of care recipients. When given the option, many receiving consumer-directed care prefer hiring relatives. ${ }^{229}$ These caregivers are unlikely to work for other clients, and are more likely to continue caring for their relative without any compensation. After all, this is what many had done before becoming an independent provider was possible.230 Therefore, if the rule forces states to eliminate or shrink jobs for independent providers, these providers may leave the labor force entirely.

225 Stacy Dale et al., How Do Hired Workers Fare Under ConsumerDirected Personal Care?, 45 The Gerontologist 583, 588 (2005).

${ }^{226} I d$.

227 E-mail from Allison Barkoff, Dir. of Advocacy, Bazelon Ctr. for Mental Health Law, to Emily Munson (Oct. 8, 2015, 8:35 PM EST) (on file with author).

228 Medicaid Offering Participant-Directed Long-Term Care Services, AHC MEDIA (Mar. 1, 2011) http://www.ahcmedia.com/articles/129911medicaid-offering-participant-directed-long-term-care-services [http:// perm.cc/8LBR-F9KY].

${ }^{229}$ Newcomer, supra, at 140.

${ }^{230}$ Kathryn G. Kietzman et al., Whose choice? Self-Determination and the Motivations of Paid Family and Friend Caregivers, 44 J. OF CoMP. FAM. STUD. 519, 531 (2013). 


\section{CONCLUSION}

Home care workers deserve wages that reflect the importance and value of their work. People with disabilities deserve choice in how their activities of daily living are conducted and who provides assistance, as well as possess the right to live in the community. Rather than working with both of these groups to develop a feasible solution honoring the interests of those directly involved in home-based caregiving, the DOL took it upon itself to act. 231

Perhaps the DOL was acting with the best of intentions. Nevertheless, those within the Beltway especially should know where good intentions lead. People with disabilities are at risk of perishing in hell on earth ${ }^{232}$-nursing homes and other institutional placements. Even if they manage to stay in their homes, access to the community will be limited, continuity of care will be diminished, and respect for privacy and personal autonomy will fade away.

Those providing care will not fare better. As states experiment with home care methods, some will lose their jobs, others will merely lose the autonomy gained by serving as independent providers. Job satisfaction will diminish, as workers are torn away from their favorite clients and limited in the types of assistance they can provide, despite their own desires to help.

Disability advocates and home care workers must come together with a coherent strategy. First, and most quickly, Congress could once again attempt to remove regulatory power over domestic service provisions of the FLSA from the Executive Branch. This legislation would result in decisionmakers being accountable to voters. Second, the DOJ must

${ }^{231}$ Letter from Cathy Cranston and David Wittie to Senator Harry Reid, Senator Mitch McConnell, and Speaker John Boehner (Nov. 11, 2014), available at https://view.officeapps.live.com/op/view.aspx?src= http $\% 3 \mathrm{~A} \% 2 \mathrm{~F} \% 2 \mathrm{Fwww}$.ancor.org\%2Fsites\%2Fdefault\%2Ffiles\%2Fnews \%2Fadapt_-_dol_congress_letter.doc [http://perma.cc/E5CT-B8QY]. Although the DOL spoke with union officials while developing the proposed regulations, people with disabilities were excluded from the discussion. Id.

232 Real Life Nursing Home Horror Stories, ADAPT, http://www.adapt.org/cca.rlnhhs [http://perma.cc/3Q9R-4EWL] (last visited Apr. 11, 2016). 
be vigilant of Olmstead violations and repeatedly remind states of their responsibility to place individuals with disabilities in the least restrictive environment.

Longer-term solutions must also be considered. Congress must develop a comprehensive strategy for the provision of long-term care. Although the Patient Protection and Affordable Care Act is a start, its more inclusive provisions were removed prior to passage. ${ }^{233}$ The 2016 election will be a good opportunity for candidates to introduce and discuss their plans for amending the healthcare delivery system, including methods of delivering long-term care. Additionally, emphasis must also be placed on raising Medicare reimbursement rates, which may drive individual states to similarly raise Medicaid reimbursement rates. If advocates had started there, perhaps the home care rule would not be the threat that it is today.

233 Associated Press, House Votes to Repeal CLASS Act, POLITICO (Feb. 1, 2012, 11:46 PM), http://www.politico.com/story/2012/02/housevotes-to-repeal-class-act-072353 [http://perma.cc/XVD5-DCH2]. The Community Living Assistance Services and Supports (CLASS) Act would have permitted individuals, including those with disabilities, to participate in a voluntary long-term care insurance program. In the event that a participant would become disabled and need long-term care, they would receive a daily cash allowance to pay for care. Thus, the individual would be free to make their own care arrangements, free from Medicaid or Medicare restrictions. 